\title{
Sustainability Report
}

National Renewable Energy Laboratory (NREL) 2003-2004

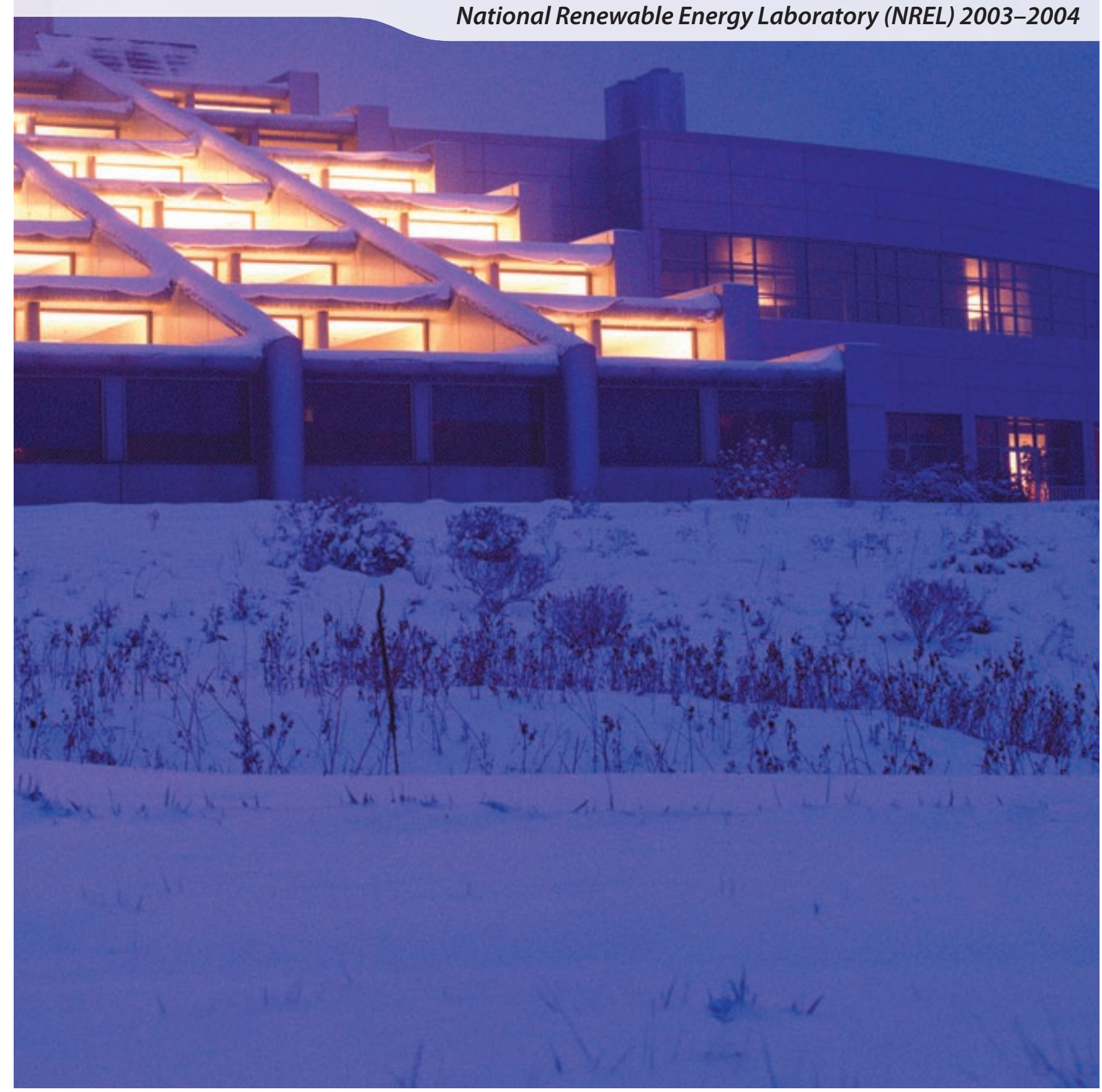





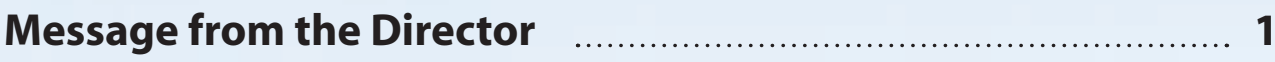

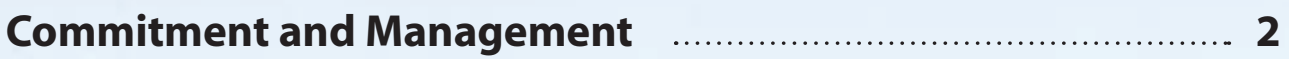

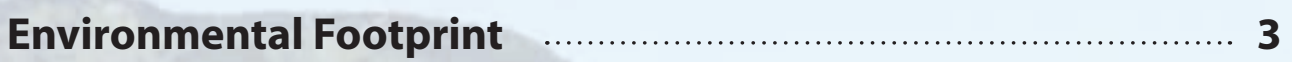

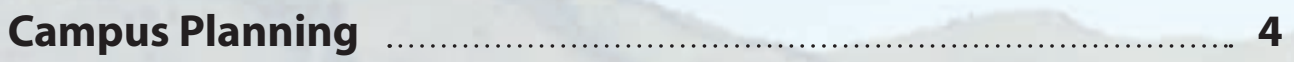

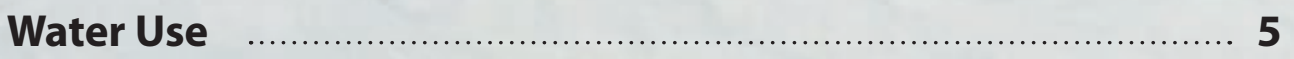

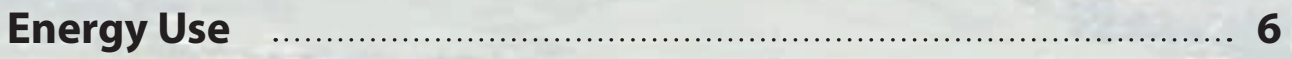

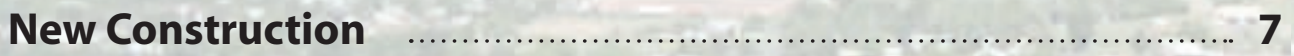

Green Power

Transportation ………… 9

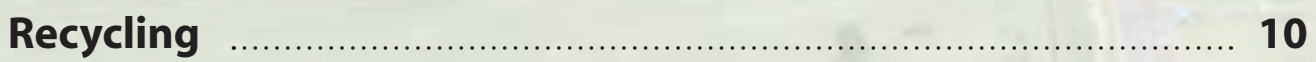

Environmentally Preferable Purchasing …………................ 11

Greenhouse Gas Emissions ………… 12

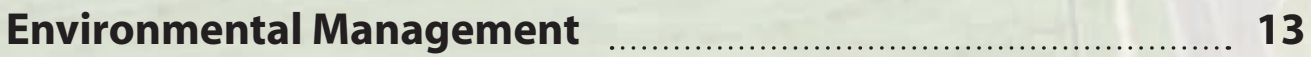

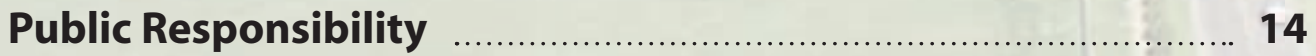

Message from the Sustainable NREL Lead ……….................. 15

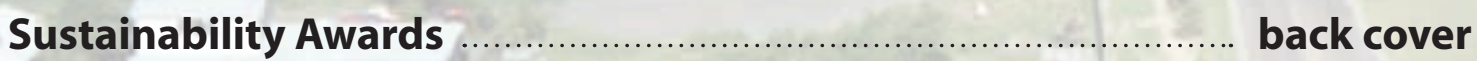

\section{Acknowledgments}

The Sustainable NREL Master Plan implementation is managed by Robert Westby,

Sustainable NREL lead; and Susan Huffnagle, Sustainable NREL coordinator.

The following staff members implement the master plan through collaborations of their individual areas: NREL Executive Management (Lab economic viability); Nancy Carlisle (environmental stewardship activities - site planning and new buildings); Stephanie Tanner (water); Otto VanGeet and Anna Hoenmans (electricity and natural gas use); Dan Bilello (GHG reductions); Chandra Shah (green power purchasing); Don Reed, Henri Hubenka, and Computer Power Management Committee (computer power management); Tim Peele (transportation); Karri Bottom and the Recycling

Advisory Committee (materials); Maureen Jordan and Denise Rayborn (environmental management systems - including sustainability); Michelle Kubik (communications); Laura Michael (policies and procedures); Lee Boughey (public responsibility). 


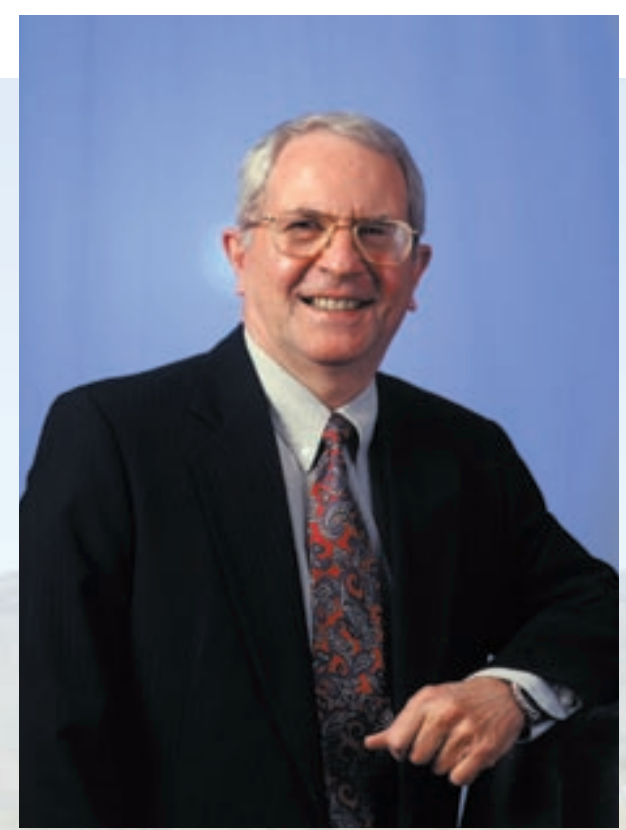

"NREL's primary goal is to establish a formal change in Laboratory culture, ensuring that every decision we make fully considers all resource implications. When sustainability is an inherent part of everything we do at the Lab, we know that we will have achieved our objective."

\section{MESSAGE FROM THE DIRECTOR}

n October 2000, I announced the creation of the Sustainable

NREL Initiative. The purpose of this initiative was to help the Laboratory seize every opportunity to ensure that the choices we make today maintain our economic viability, minimize our impact on the environment, and ensure the well-being of our staff and the public far into the future. Subsequently, the accomplishments in the planning stage of this initiative succeeded in laying important groundwork for our journey toward a more sustainable Laboratory.

In February 2002, NREL made the transition from planning to a focus on implementing actions that would lead to a sustainable operating culture. Sustainable NREL activities are organized around a comprehensive Sustainability Management Framework, which is based on the "triple bottom line" of sustainability-economic viability, environmental stewardship, and public responsibility.

This report summarizes the status of Sustainable NREL activities for 2003-2004. I am pleased to report that we have made considerable progress in all areas. Here are a few of the highlights:

- The Lab substantially reduced its energy use, meeting both DOE 2005 and 2010 goals in 2003.

- NREL was one of seven organizations to initially establish greenhouse gas emissions (GHG) reduction targets as part of the EPA Climate Leaders Partnership.

- NREL has purchased $10 \%$ of its annual electrical use in green power since 2001.

- The Lab completed its 25-year General Development Vision, which encourages sustainability through an overall development plan.

- NREL's next major new building, the Science and Technology Facility (STF), was designed at the Gold level of the Leadership in Energy and Environmental Design (LEED) guidelines.

- The Lab's fleet of 39 fleet vehicles includes 29 alternative-fuel vehicles.

- NREL has reduced its water use by $25 \%$ since 2000 .

NREL's primary goal is to establish a formal change in Laboratory culture, ensuring that every decision we make fully considers all resource implications. When sustainability is an inherent part of everything we do at the Lab, we know that we will have achieved our objective.

\section{Richard Truly}

Director, National Renewable Energy Laboratory September 2004 


\section{NREL Sustainability Vision}

NREL will exemplify sustainability in an R\&D organization by maximizing efficient use of all resources; minimizing waste and pollution; and serving as a positive force in economic, environmental, and community responsibility.

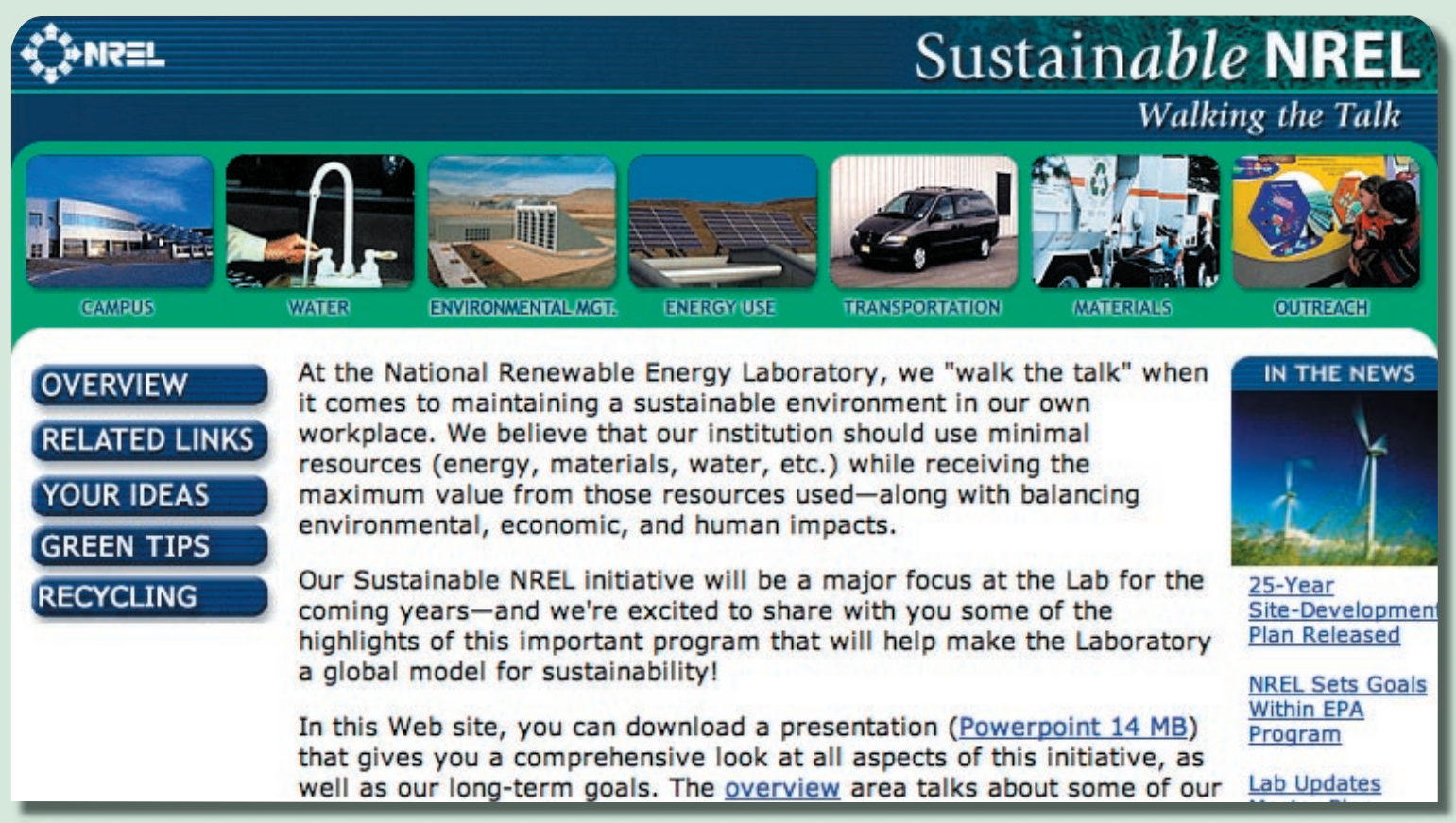

\section{http://www.nrel.gov/sustainable_nrel/}

7 he Sustainable NREL Master Plan and Management Framework provide the foundation for sustainability activities that are implemented collaboratively throughout the Laboratory. For more information, please visit our Web site.

\section{Sustainability Management Framework}

\section{Economic Viability}

Environmental Stewardship

- Campus

- Water

- Electricity/Natural Gas

- Transportation

- Reduce, Reuse, Recycle, Rebuy

- Environmental Management

- Education/Communications

Public Responsibility 
n 2004, NREL completed a life-cycle assessment-based "environmental footprint." This assessment is the baseline against which the Laboratory measures its progress in achieving "environmental neutrality" in all its operations. This goal identifies the environmental consequences of the Laboratory's choices and measures the cumulative effect of those choices using a functional $\mathrm{CO}_{2}$ common denominator. The use of this universal metric allows NREL to better understand the relative impacts of its decisions; measure progress toward sustainable neutrality; benchmark performance against goals and other similar institutions; and, in general, take responsibility for its actions.

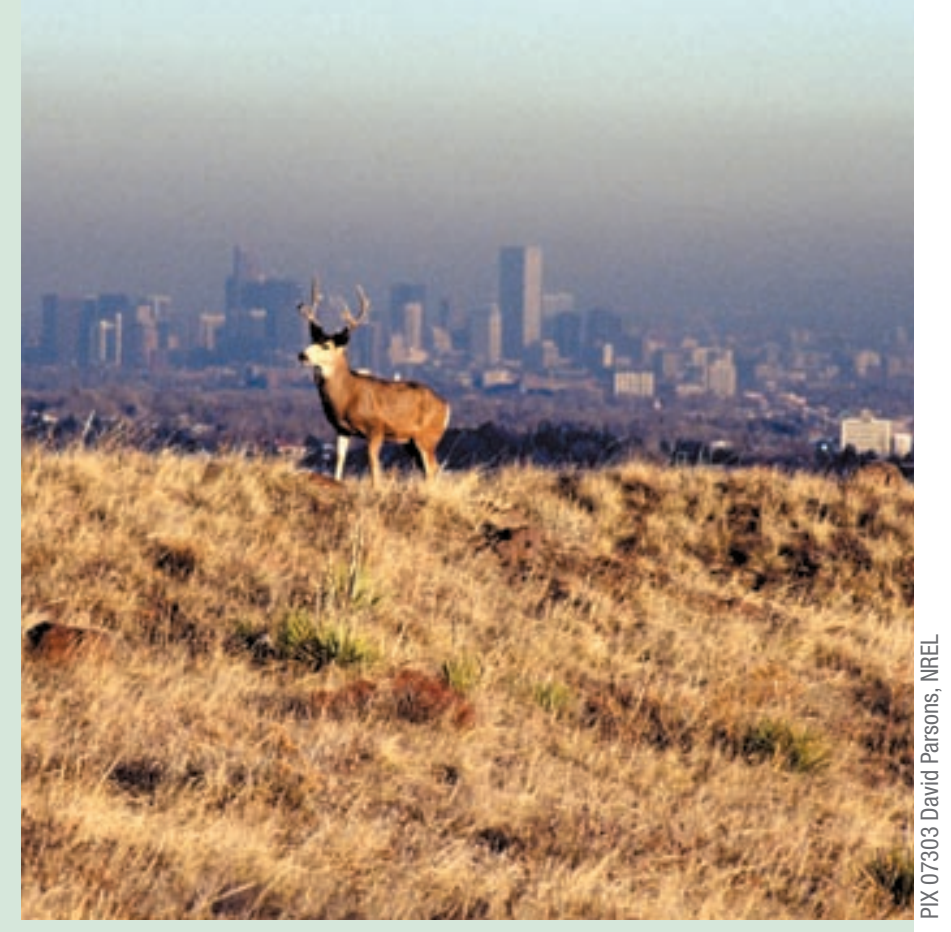

\section{Laboratory $\mathrm{CO}_{2}$ Source Distribution} (\% $\mathrm{Kg} \mathrm{CO}_{2}$ Equivalent)

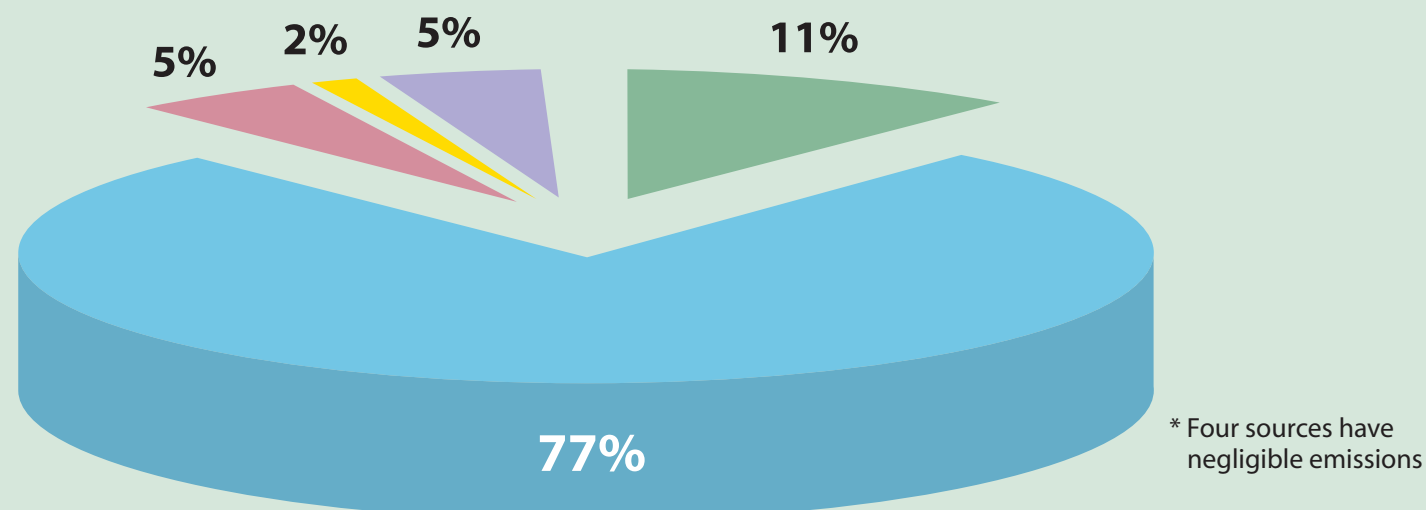

\begin{tabular}{llcc} 
SOURCE & Total for FY03 & $\mathbf{K g ~ C O}_{2}$ Eq. & \% of Total $\mathrm{CO}_{2}$ Emitted \\
Electricity & $21,777,183 \mathrm{kWh}$ & $22,299,835$ & $77 \%$ \\
\hline Natural Gas & $62,046 \mathrm{MMBTU}$ & $3,275,408$ & $11 \%$ \\
\hline Commuter Vehicle Emissions & 227,069 gallons gas & $1,475,949$ & $5 \%$ \\
\hline Domestic Air Travel Emissions & $6,689,199$ miles & $1,373,648$ & $5 \%$ \\
\hline International Air Travel Emissions & $2,107,400$ miles & 440,994 & $2 \%$ \\
\hline Fleet Vehicle Emissions & 11,267 gallons gas \& eq. & 73,236 & $*$ *egligible \\
\hline Solid Waste Disposal & $9,575,000$ gallons:201 MMBTU & 10,611 & $*$ Negligible \\
\hline Water (Electricity Consumed) & $9,575,000$ gallons: 13,581 kWh & 13,907 & * Negligible \\
\hline Water (Natural Gas Consumed) & $9,575,000$ gallons:201 MMBTU & 10,611 & $*$ Negligible
\end{tabular}

Source: Sustainable NREL: Laboratory Life-Cycle Assessment of Environmental Footprint; Susan Huffnagle, Robert Westby; NREL Report No. CP-710-36529 
REL has completed a 25-year General Development Vision (GDV), establishing an overall development plan that encourages sustainability by discouraging "piecemeal" building additions. This unique plan proposes incorporating leading-edge renewable energy and energy efficiency technologiesas well as environmentally sound energy, alternative transportation, and water efficiency practices-into NREL's buildings and the surrounding environment. The plan sets goals for land development and building design that will maximize resource efficiency, minimize waste, enhance people's work environment, and help NREL achieve its energy mission.

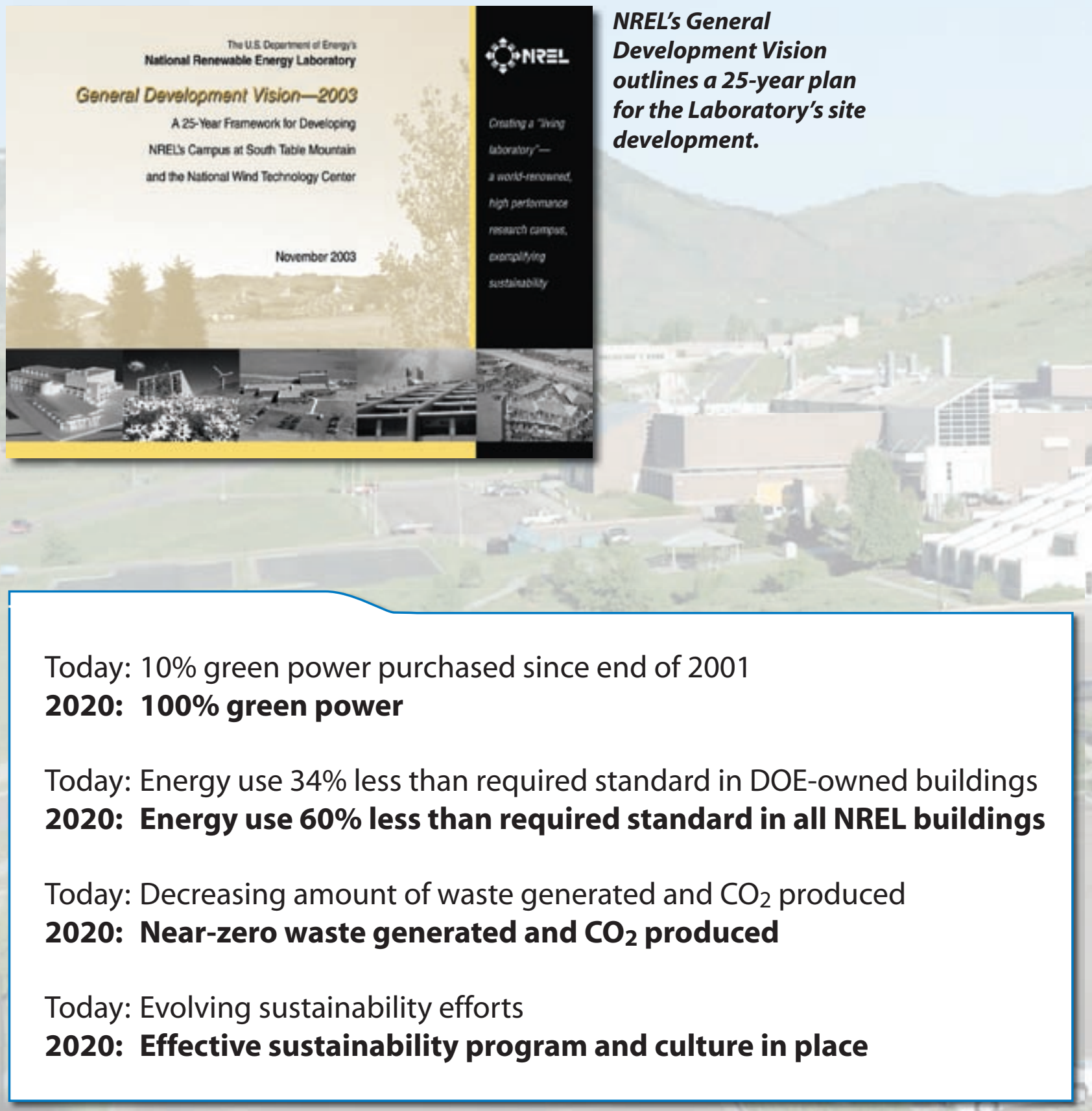




\section{WATER USE}

N REL has developed life-cycle cost-effective water efficiency programs that include an extensive water-management plan.

In addition, four water-

conservation best management practices have been implemented. They include educating staff about water conservation, utilizing natural landscaping, installing low-flush toilets and waterless urinals, and retrofitting faucets and showerheads with aerators to decrease water flow.

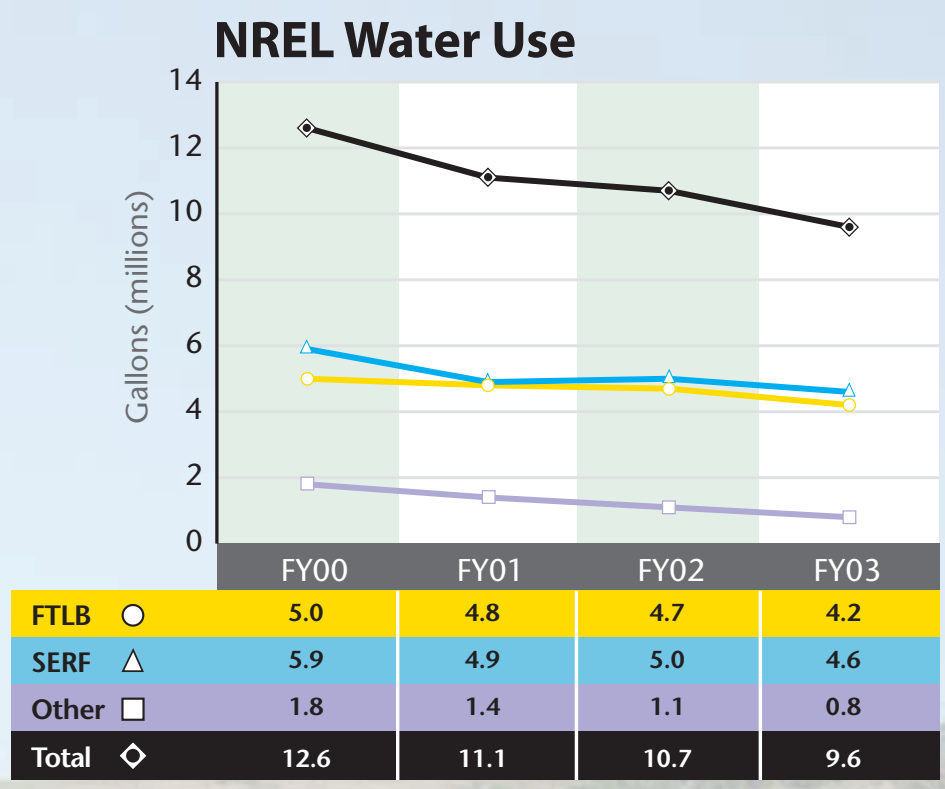

Best management practices have enabled NREL to reduce water consumption by $25 \%$. This has allowed water costs for the Laboratory to remain constant since FY 2000.

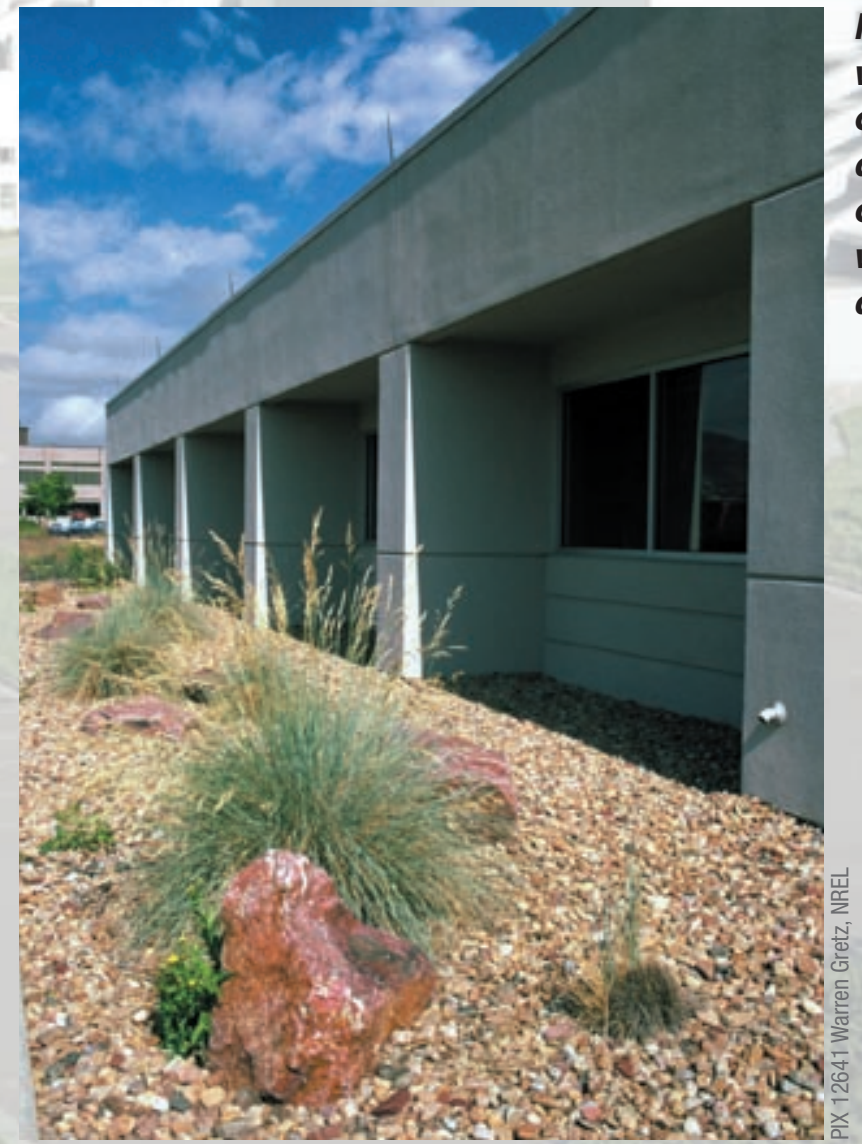

Natural landscaping is one way NREL is reducing water consumption. Using plants that are native to the environment creates harmony between water conservation and aesthetic beauty. 
W hen it comes to electricity and natural gas consumption, NREL has a unique challenge as a research and development institution. The Laboratory works to strike a balance between energyuse reduction without compromising its scientific endeavors.

Seventy-seven percent (77\%) of the Laboratory's $\mathrm{CO}_{2}$ emissions come from electricity use. In response, NREL has focused on lowering electricity consumption through energy efficiency retrofits on existing buildings and sustainable new-building construction. A primary electrical cost-saving opportunity is peak load management.
NREL has installed meters on all Lab-owned buildings to measure use and peak demand. This data is used to program the Laboratory's energy management control systems and to serve as the basis of its Demand Management Program.

The federal government has established energy-use goals, which NREL

already has met and exceeded. The Lab continues to actively pursue all cost-effective, energy-use reduction opportunities.

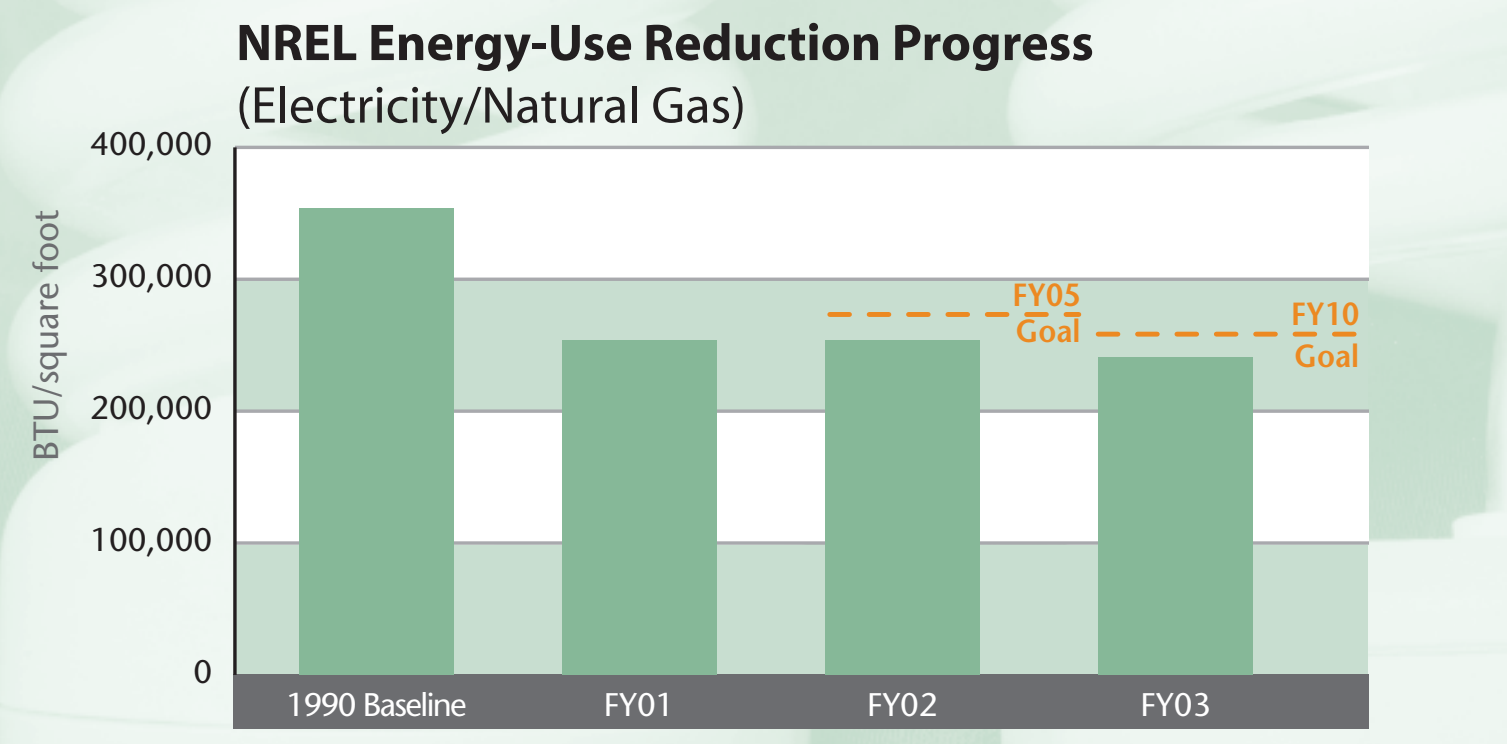




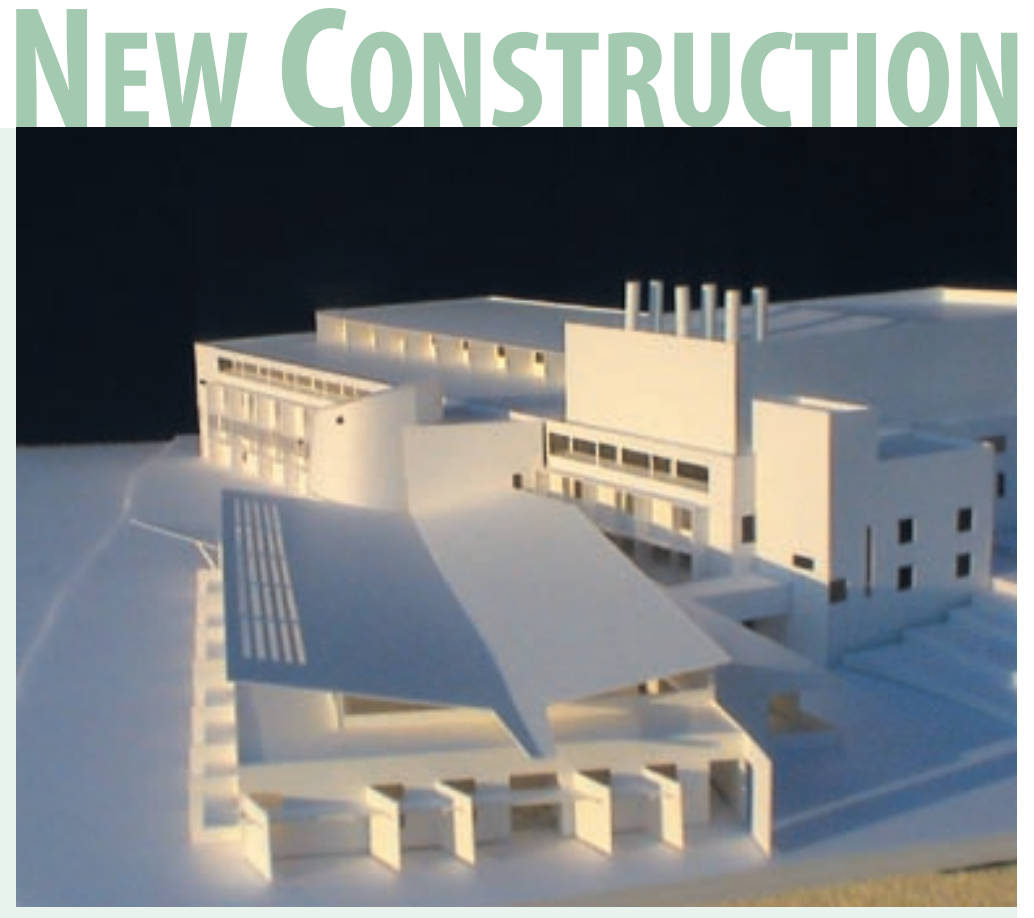

exceed the Federal Model Energy

Code by at least $30 \%$. NREL's

newest building, the Science

and Technology Facility (STF), is

The Science and Technology Facility (STF), which will achieve a Gold rating in the LEED program, is a significant project for the Lab. NREL is one of six federal facility Pilot Partners of Labs for the 21st Century (LF21C).

designed to achieve the Gold level.

Laboratory buildings, as a building type, present unique challenges with regard to energy performance. For example, a laboratory building needs 10 to 15 times the number of "air changes" as compared to a regular office building. The U.S. Environmental Protection Agency (EPA) and the U.S. Department of Energy (DOE) have created Labs for the $21^{\text {st }}$ Century (LF21C), a voluntary program dedicated to improving the energy performance of U.S. laboratory buildings.
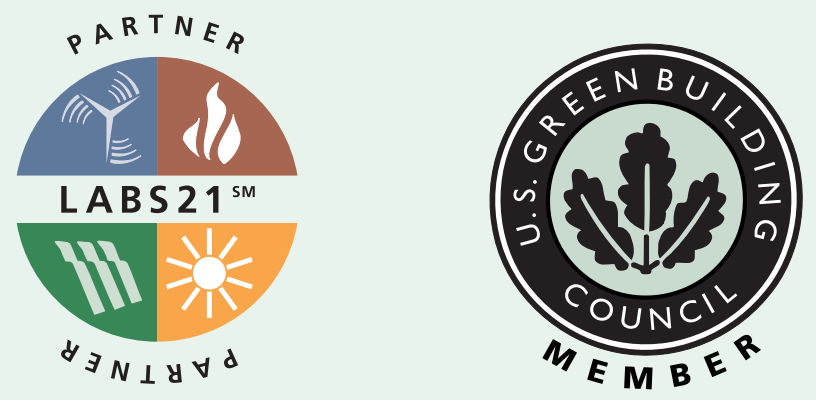


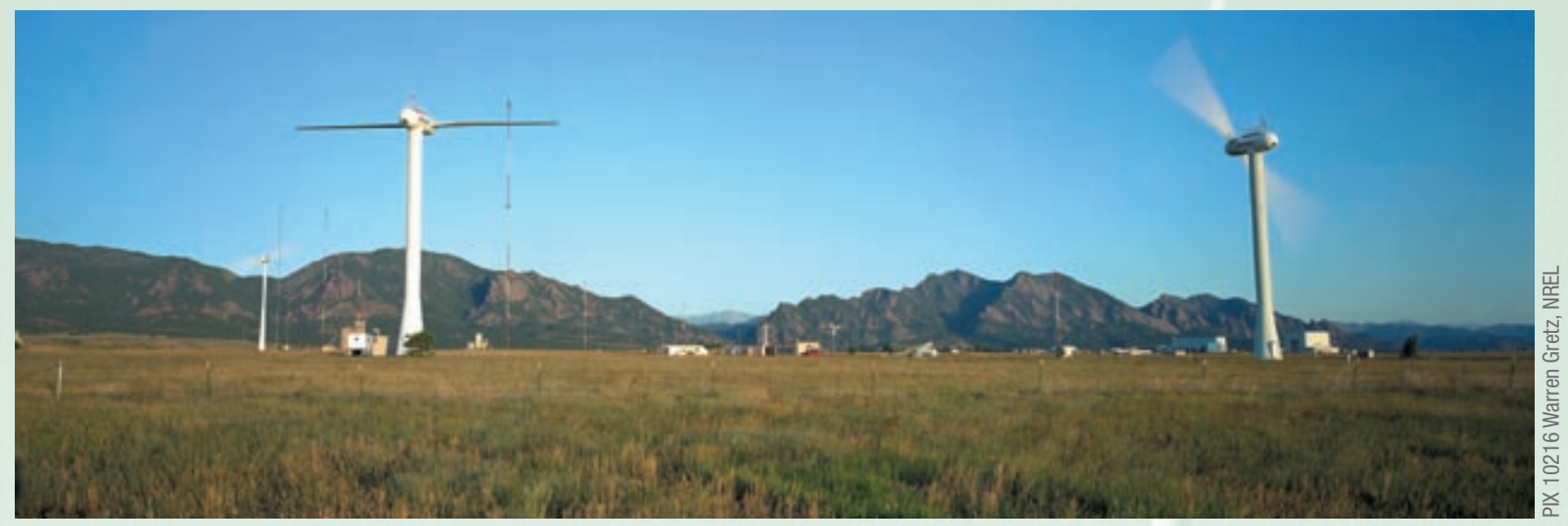

The NREL National Wind Technology Center (NWTC) provides on-site generation.

ince 2001, NREL has purchased $10 \%$ of its annual electrical use in the form of wind power from its local utility. The Laboratory is currently exploring the redirection of that purchase to help facilitate the start-up of rural Colorado wind projects.

In addition to its green power purchases, NREL uses renewable energy technologies for on-site generation. Electricity generated during research and development activities at the National Wind Technology Center (NWTC) simultaneously offsets site electrical load. There also are applications of photovoltaics on the main campus of the Laboratory.

\section{Photovoltaic cells are located on NREL's site entrance building and Solar Energy Research Facility (SERF).}

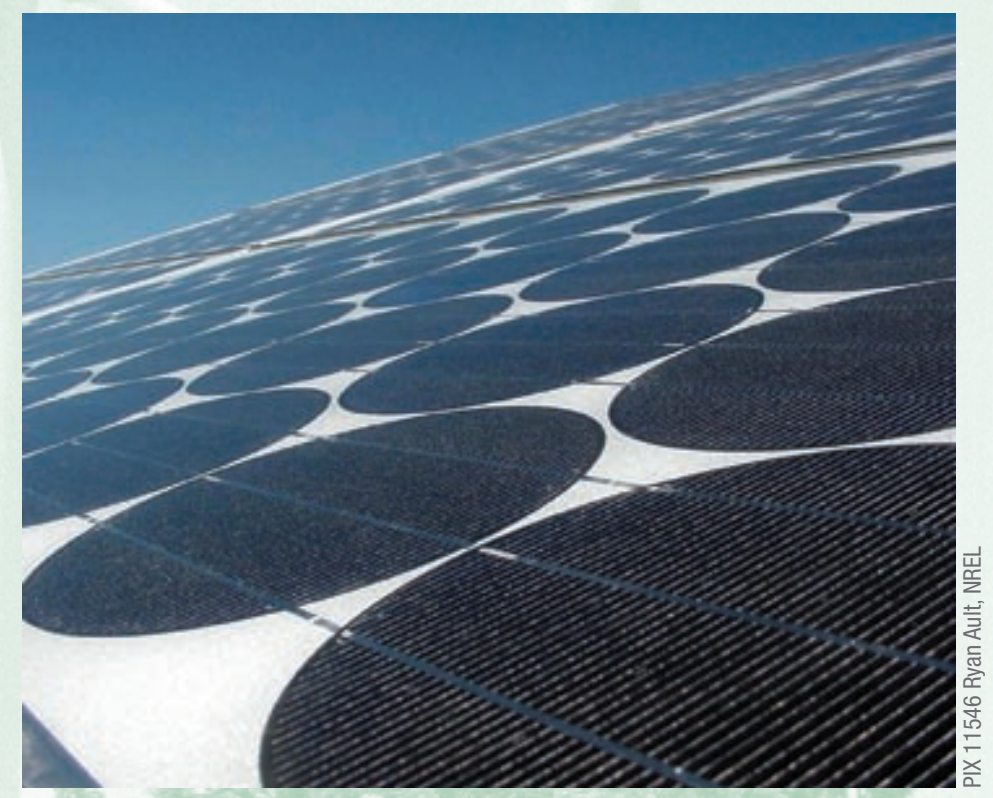


n FY03, NREL calculated the

breakdown of miles traveled by employees via commuting, air travel, and the NREL fleet. NREL has reduced air travel-which was the largest portion-through the installation of teleconferencing equipment. Thirty-one trips were saved in FY03 alone.

Employee commuting also contributes significantly to the miles traveled.

Recently, NREL conducted a commuter survey and determined that nearly $36 \%$ of NREL employees participate in some form of alternative commuting. Through NREL's promotion efforts, employees enjoy the benefits of free bus passes;

Web links to carpool/vanpool sites; and lockers, showers, and safety vests for bike commuters.

The Department of Energy (DOE) has set petroleum fuel-use goals for federal fleets. The goal for NREL is 9,800 gallons annual use by 2005. NREL has reduced petroleum use from 12,250 gallons in 1999 to 8,500 gallons in 2003. This goal was accomplished by the increased use of alternative fuel vehicles (AFVs) - NREL's fleet of 39 vehicles includes 29 AFVs.

\section{NREL Staff Total Miles Traveled in FY03}

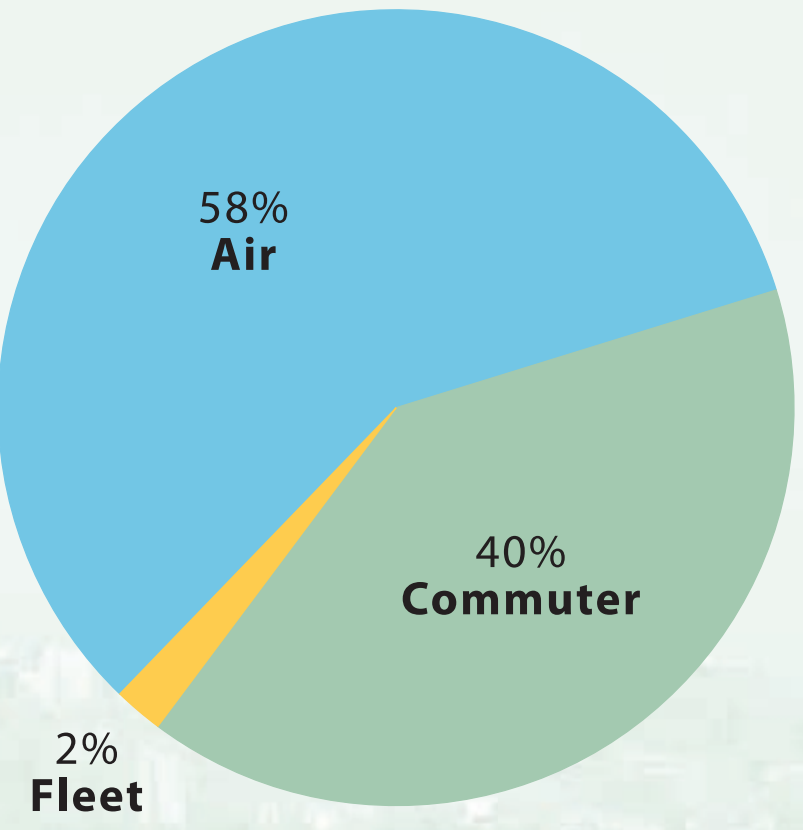

\% Breakdown of Total Miles

NREL Fleet Petroleum Use

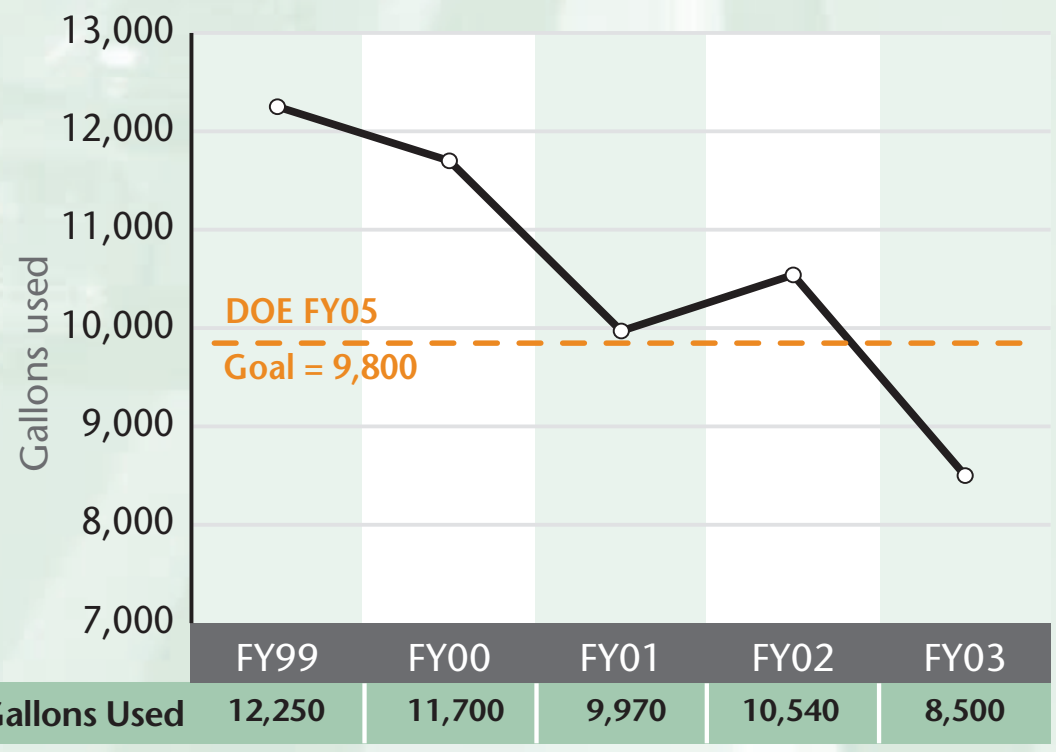


REL's comprehensive recycling program, which began

as a voluntary program in the early 1990s, has evolved into a formal Laboratory activity led by an internal Recycling Advisory Committee.

The program consists of 14 separate recycling centers that are on-site collection points for corrugated cardboard, all types of paper, aluminum, glass, plastic containers, toner cartridges, and packing peanuts. In addition, batteries, fluorescent lightbulbs, and scrap metals are collected and recycled. In FY03 alone, NREL increased its recycling by $12 \%$ from FY02, while decreasing paper consumption.

\section{FY03 Total Waste Stream}

(664,008 lbs.)

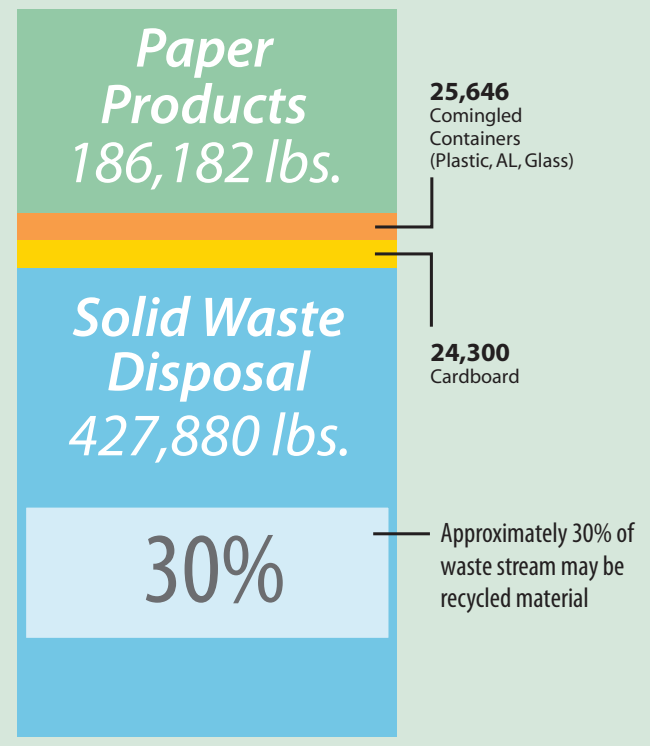

In 2003, NREL recycled $36 \%$ of its total waste, and is actively working to eliminate all recyclables from the waste stream.

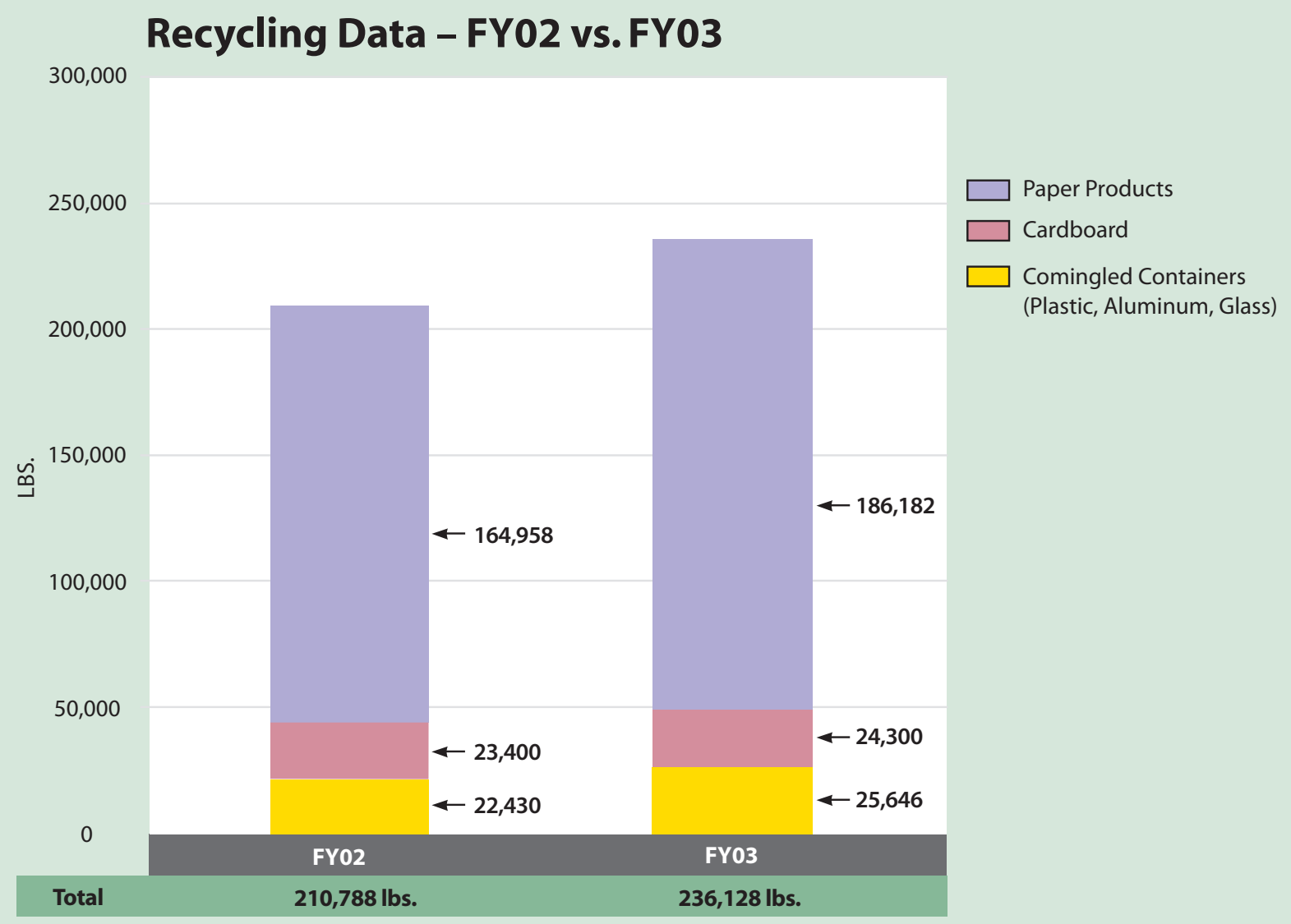




\section{ENVIRONMENTALLYY PrEFERABLE PURCHASING}

Cederal directives have established goals for environmentally preferable purchasing. Federal agencies consider factors such as the amount of recycled content in products, use of bio-based and recovered materials, reuse of products, and the ultimate recyclabillity of products.

One hundred percent (100\%) of all Laboratory carpet, toner cartridge, and office paper purchases have recycled content.

\section{Key Efforts}

Duplex modules were installed on all 77 network printers, which default to the double-sided printing option.

As of FY 2001, NREL no longer purchases equipment containing CFC, HCFC, and Halon.

Whenever possible, NREL purchases Energy Star Products, energy-efficient computer equipment, and LCD monitors.

In FY 2005, NREL will require that its office supply vendor offer a "green-only" purchase catalog.

In FY 2003, 74,334 pounds of paper was purchased and 186,182 pounds was recycled. To address this challenge in FY 2005, NREL will establish an Electronics Processing Initiative that will reduce the amount of paper coming into the Laboratory from outside sources.

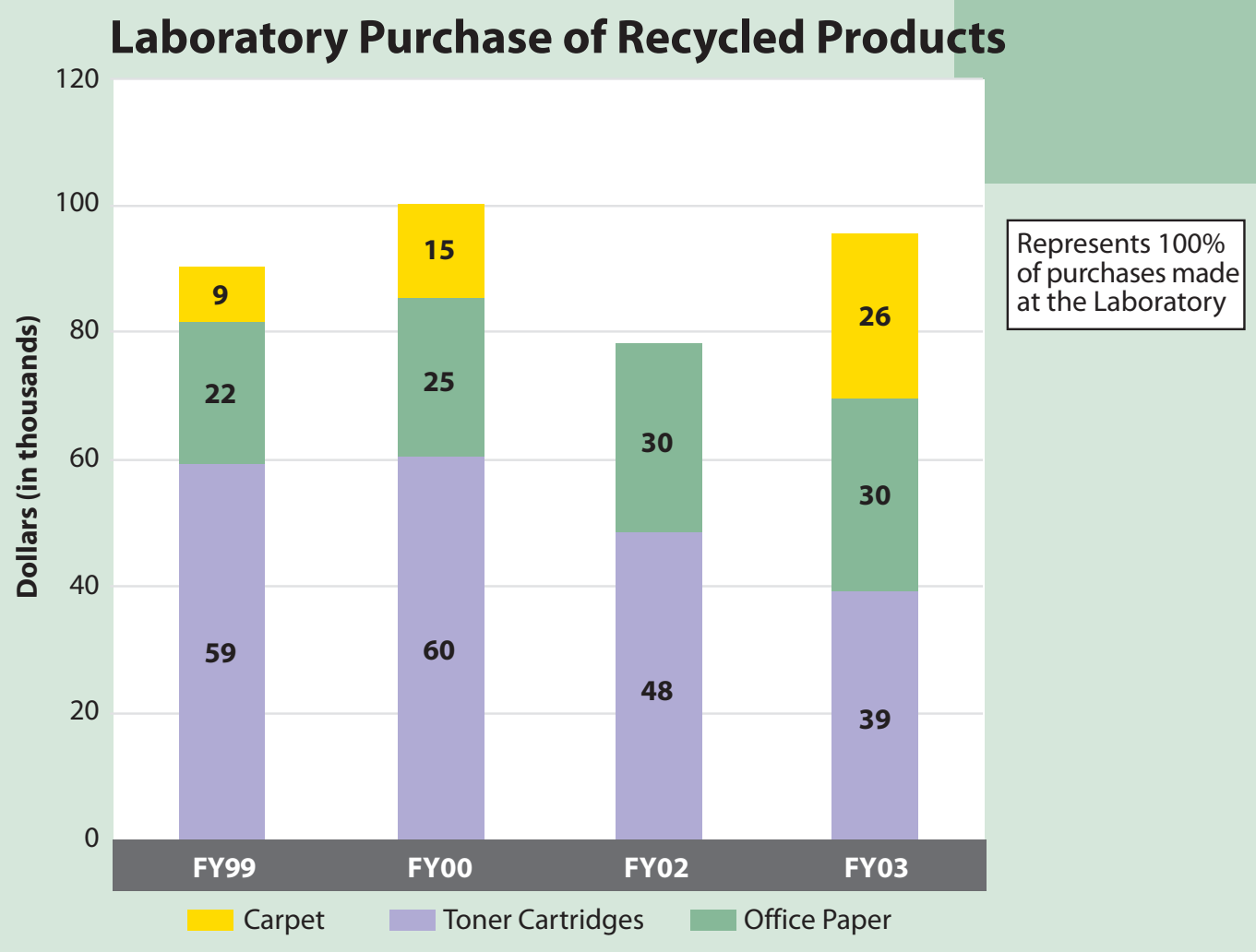




\section{GREENHOUSE GAS EMISSIONS}

The EPA Climate Leaders Partnership is

a voluntary program that challenges partners to set aggressive greenhouse gas (GHG) emissions-reduction goals. NREL, which was the first federal pilot partner of the program, is one of seven members to initially establish a target reduction.

NREL's goal is to reduce GHG emissions by $10 \%$ by FY05 vs. the FY00 baseline. The Laboratory is actively implementing retrofits, constructing energy-efficient and sustainable new buildings, implementing energy-saving programs throughout the Laboratory, and increasing its "green power" purchases to reduce emissions.

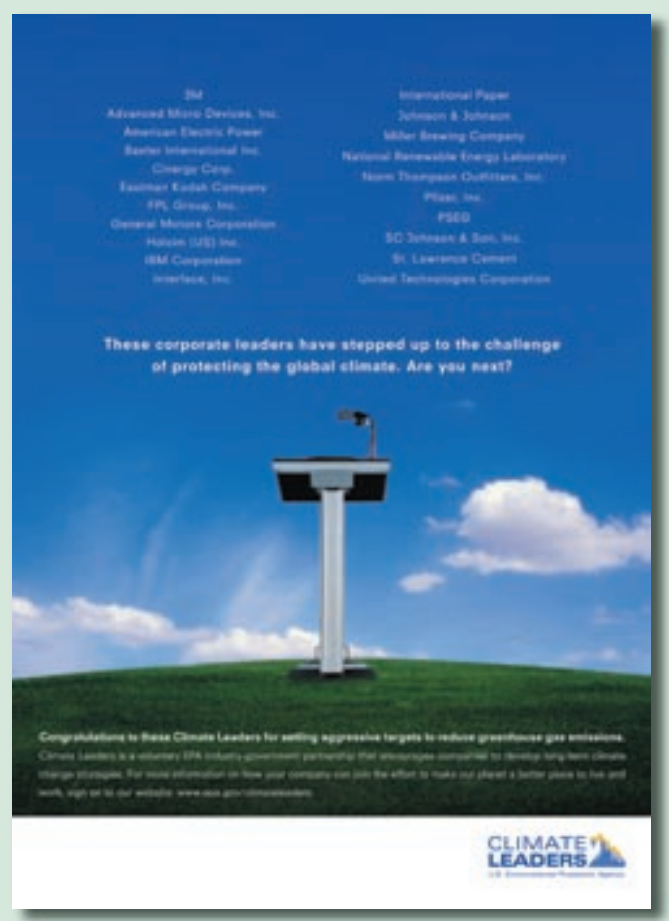

EPA Climate Leaders is a program that aids companies in their goals to reduce greenhouse gas emissions.

\section{GHG Emissions Reductions}

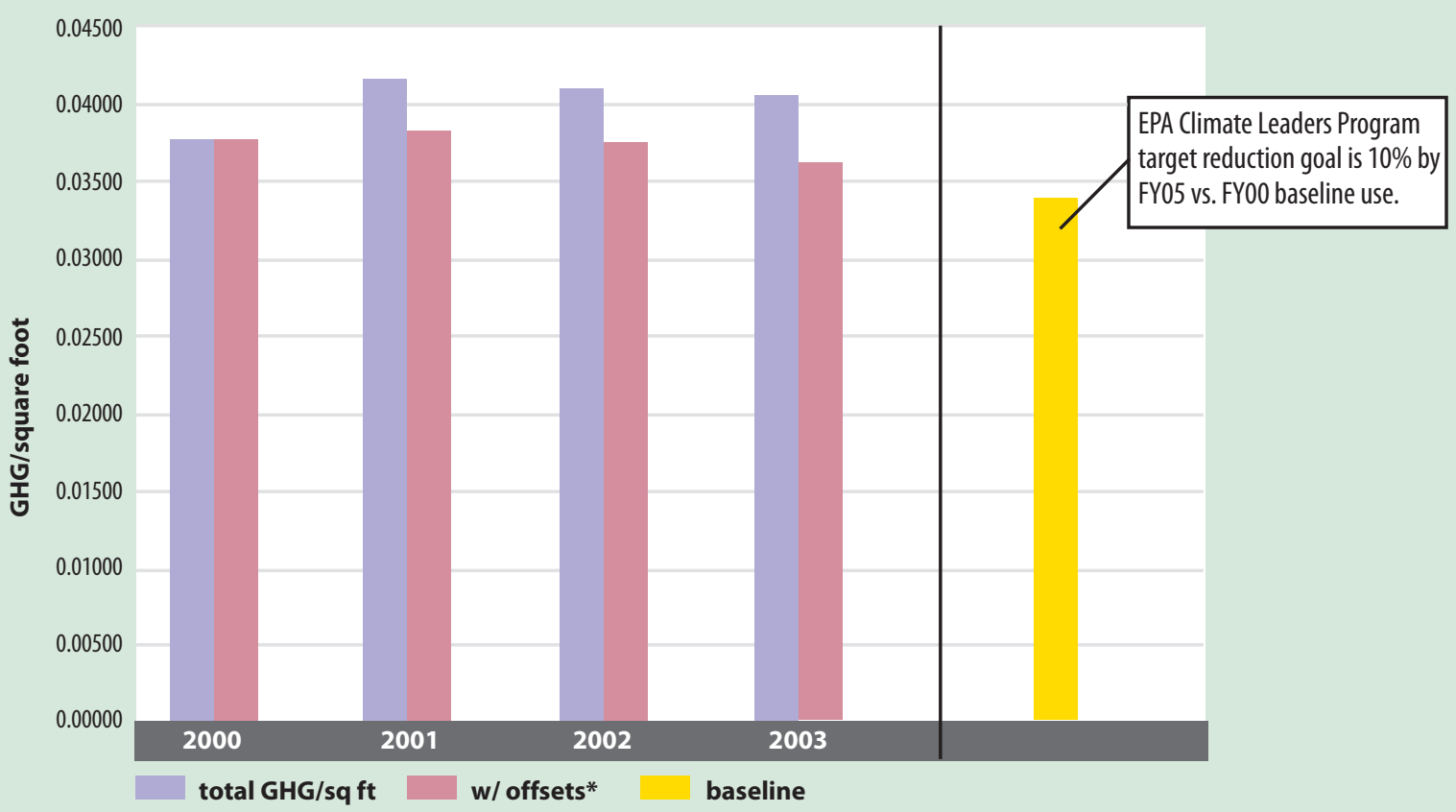

* Offset based on green power purchase (wind power) of $10 \%$ of annual electrical use

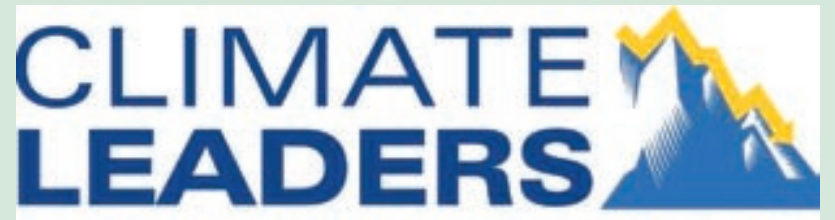

U.S. Environmental Protection Agency 
N REL has implemented an

Environmental Management System

(EMS) as required by federal directives.

These activities focus on incorporating

environmental considerations into

normal management processes, as well

as improving internal environmental

management effectiveness. These activities

focus on efforts such as natural and cultural

resource protection, pollution prevention,

and waste management.

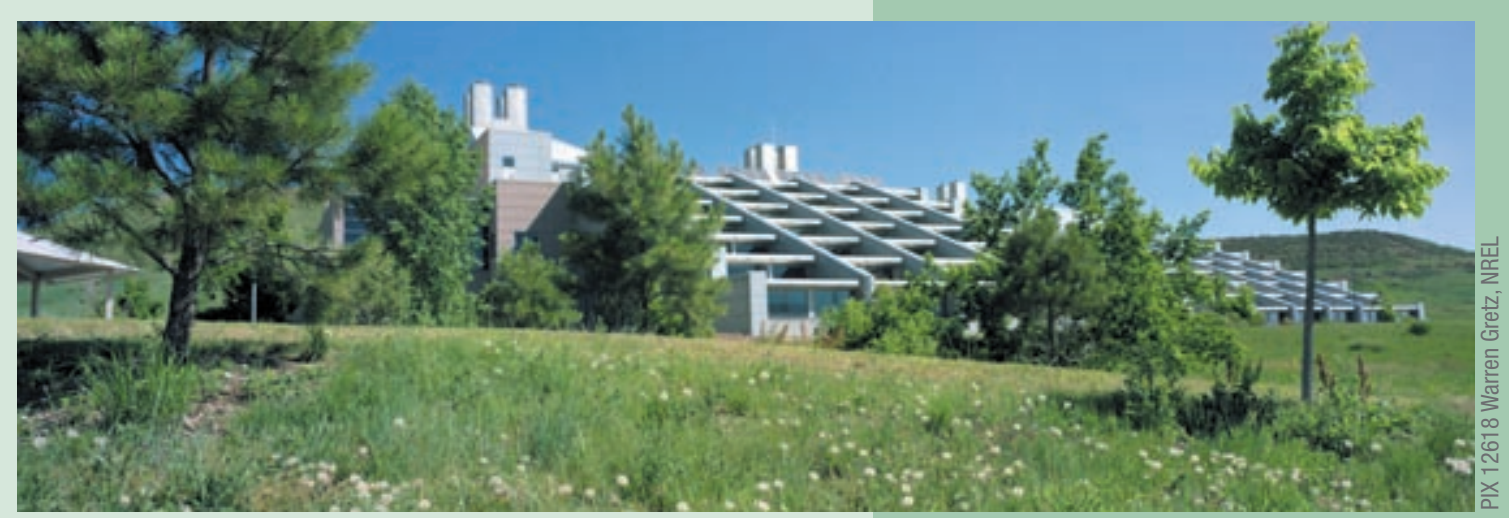

NREL prepares an annual environmental management report, summarizing NREL's environmental protection programs and activities. It is organized according to the different environmental media (e.g. air, waste, ground water, etc.), and includes a brief summary of:

- How the program is managed in that area,

- Any permitting or notification efforts that are ongoing or have been completed during the reporting period, and

- Activities that have occurred during the reporting period in that environmental area.

Copies of these reports are available at http://www.nrel.gov/sustainable_nrel/ environmental_manage.html
NREL was accepted into the Environmental Protection Agency's (EPA) National Environmental Performance Track (NEPT) program. One of 39 new members from 22 states, the Laboratory was recognized for its impressive record of environmental management and performance. NREL's successful Environmental Management System (EMS), augmented by the Sustainable NREL program, was recognized for its continuous environmental improvement in FY04.

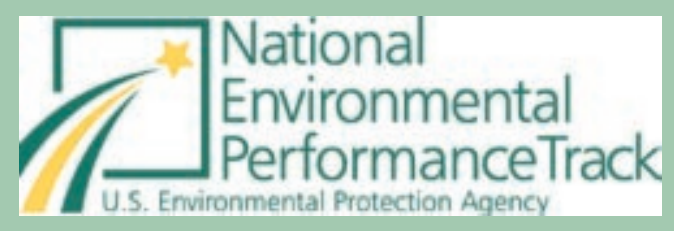




\section{PUBLIC RESPONSIBILTY}

P ublic responsibility is one of the three primary elements of the Sustainability Management Framework. NREL works proactively to support the transferability of its sustainability activities and to educate others about sustainability through a variety of outreach mechanisms.

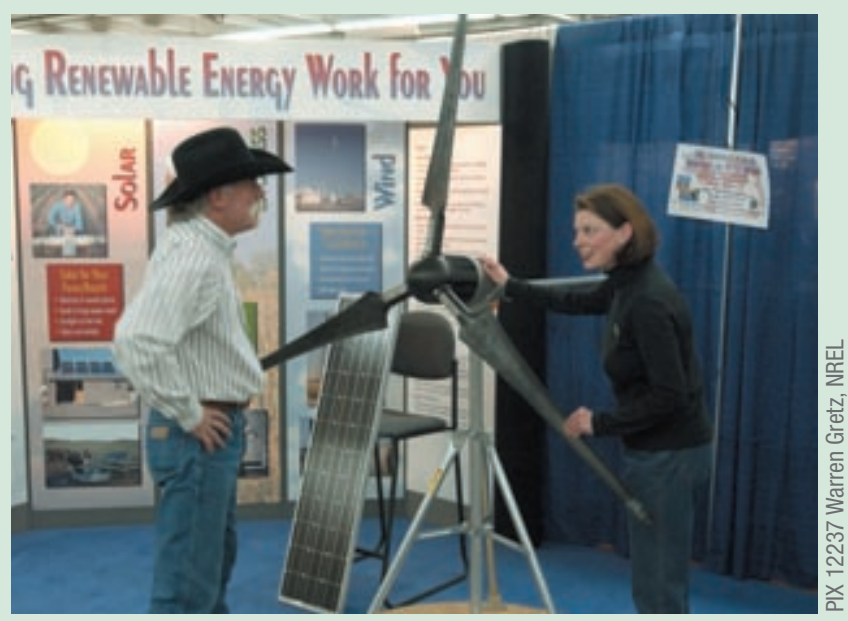

NREL promotes sustainability at several outreach events, including the National Western Stock Show in Denver.

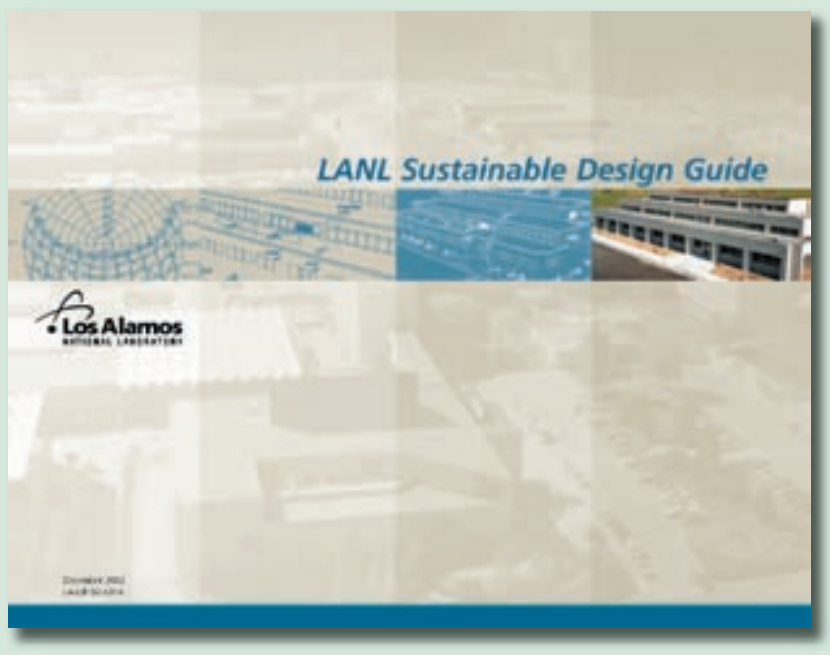

\section{Key Efforts}

NREL has been recognized

through awards programs and has demonstrated its leadership in national programs (see Sustainability Awards).

The Laboratory has developed transferable sustainability tools such as the new building Sustainable Design Guide (SDG).

NREL is a member of and supports multiple state, regional, and national stakeholder organizations.

The Laboratory conducted a two-day conference on Sustainability Management Systems (SMS) with nearly 70 attendees nationwide.
The first Sustainable Design Guide (SDG) was developed for Los Alamos National Laboratory and is being actively offered to federal and state facilities. A generic version of the SDG has been posted for general use on the DOE Buildings Web site; and the American Society of Heating, Refrigerating, and Air-Conditioning Engineers (ASHRAE) is considering adopting it as a model. The guide can be accessed at http://www.eere.energy.gov/buildings/ highperformance/lanl_sustainable_guide.html 


\section{MESSAGE FROM THE}

W e are pleased to have completed our first NREL Sustainability Report. It has been rewarding to be associated with Sustainable NREL, which enjoys the unequivocal support of NREL's executive management, our Department of Energy (DOE) sponsors, and-most important-the individuals who make up the NREL staff.

We have implemented a program in the broadest sense of sustainability, which is based on a "triple bottom line" foundation. Our sustainability management framework includes the primary elements of economic viability, environmental stewardship, and public responsibility. We have made outcome-based implementation a priority, and established metrics to baseline and measure progress in order to drive accountability.

We have been able to mature our activities significantly since 2002 and make progress toward measurable outcomes. Continued progress will require increasingly enhanced efforts to which we are committed. Our focus in the next year will be on capturing the benefits of further institutionalizing the overall sustainability ethic at the individual staff-member level; working toward the overarching goals of "environmental neutrality" and "near-zero waste"; and completing a program assessment against comprehensive sustainability performance-reporting frameworks such as the Global Reporting Initiative (GRI) Sustainability Reporting Guidelines.

I want to personally thank those individuals previously cited in the acknowledgments section of this report. Their contributions and leadership have been-and will continue to be-key in our implementation efforts. Finally, I would like to acknowledge Laboratory Director Richard Truly for his leadership and support in institutionalizing sustainability at the Laboratory and creating Sustainable NREL as its implementation vehicle.

As a national laboratory, one of our roles is to serve as a public resource. As such, we would be pleased to share any aspect of our sustainability activities with you.

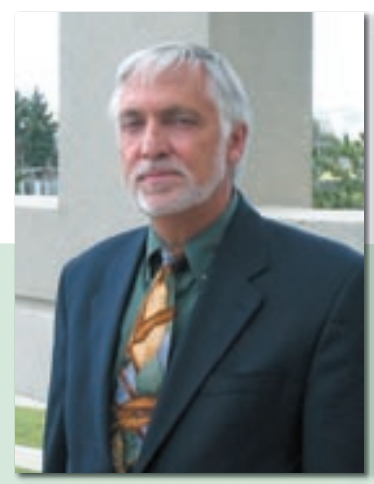

\section{Bob Westby}

Director, Energy and Environmental Applications Office; and Sustainable NREL Lead

September 2004 


\section{SUSTAINABILITY AWARDS}

2004 U.S. Department of Energy (DOE) Pollution Prevention Best-In-Class Awards: Office of Energy Efficiency and Renewable Energy (EERE)

- Sustainable NREL: New Building Program

- Sustainable NREL: Recycling Program

- Sustainable NREL: Education, Outreach, and Information Sharing

EPA National Environmental Performance Track (NEPT)

Colorado Department of Health and Environment

Environmental Leadership Program

Department of Energy (DOE) Federal Energy and Water Management Award

2003 University of Colorado Wirth Chair Award in Environmental and Community Development Policy

Department of Energy Departmental Energy Management Achievement Award: Effective Program Implementation - Sustainable NREL

2002 EPA Climate Leaders Partnership: First federal laboratory member and one of seven members to establish a target GHG emissions reduction

Labs for the $21^{\text {st }}$ Century: One of the first federal-sector labs that joined the program as a Pilot Partner in 2002

Federal Energy Management Program (FEMP) Energy Saver Showcase Award for the Thermal Test Facility (TTF)

2000

EPA Green Power Partnership: Made commitment to purchase $10 \%$ of annual electric use in wind energy and became first federal laboratory member

National Renewable Energy Laboratory

1617 Cole Boulevard, Golden, Colorado 80401-3393 303-275-3000 • www.nrel.gov

Operated for the U.S. Department of Energy Office of Energy Efficiency and Renewable Energy by Midwest Research Institute • Battelle

NREL/MP-710-36786 • September 2004

Printed with renewable-source ink on tree-free recyclable paper produced from the kenaf plant, grown and processed totally chlorine-free in the United States. 